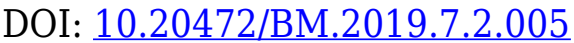

\title{
MARKETING ANALYSIS IN THE WATER PRODUCTION SECTOR IN KOSOVO. CASE STUDY “DEA WATER"
}

\author{
VJOSA FEJZA, HYKMETE BAJRAMI
}

\begin{abstract}
:
The drinking water presents a vital product worldwide to whom nowadays a special attention is being devoted. This is mainly due its lack, which is a result of to the environmental destruction caused by humankind. Therefore, providing enough drinking water presents a challenge for many countries worldwide. Kosovo has insufficient water reserves, that presents one of the main limiting factors for economic and social development in the future. In this study, a single case study approach was employed with the intention to explore and gain a preliminary understanding of the drinking water production sector. The objective of this paper is to analyze the strength and weakness of drinking water production company DEA as well as other companies in the same sector on their daily operations. Our main focus is to analyze the marketing mix of the DEA Company, the current markets in which this company is operating as well as the markets that this company aims to penetrate in the future. Objective of the paper is also to come to some valuable conclusions and recommendations for companies operating in the same sector and also those who are seeking to enter the market.
\end{abstract}

\section{Keywords:}

marketing, marketing mix, production, drinking water, SWOT analysis

JEL Classification: M31, L19, D20

\section{Authors:}

VJOSA FEJZA, University of Prishtina " Hasan Prishtina", Faculty of Economics, Kosovo, Email: vjosa.fejza@uni-pr.edu

HYKMETE BAJRAMI, University of Prishtina " Hasan Prishtina", Faculty of Economics, Kosovo, Email: hykmete.bajrami@uni-pr.edu

\section{Citation:}

VJOSA FEJZA, HYKMETE BAJRAMI (2019). Marketing Analysis in the Water Production Sector in Kosovo. Case Study "Dea Water". International Journal of Business and Management, Vol. VII(2), pp. 59-79., 10.20472/BM.2019.7.2.005 


\section{Literature Review}

The meaning of marketing is misunderstood very often. Most of the people that are not involved directly in the Marketing science believe that marketing has to do with advertising, or they may think that marketing persuades people to buy things they do not need, or it is art of selling any product no matter if it presents a value for any costumer or not. This kind of perception for marketing is more present in not developed and developing countries such as Kosovo. In Kosovo due to its late and long lasting transition from planned economy to market economy most of the firms do not deploy marketing concept at their business model. However in market economies, marketing is more than that. According to Blythe (2005), marketing is the term given to those activities which occur at the interface between the organization and its customers. In addition, according to Kotler et al. (1999), marketing is defined as a social and managerial process by which individuals and groups obtain what they need and want through creating and exchanging products and value with others. Based on those two definitions of marketing, it can be concluded that the main duty of marketing is to satisfy customer needs as well as generating profits for organizations. According to Kotler \& Armstrong, (2016): marketing is engaging customers and managing profitable customer relationships. According to them the aim of marketing is to create value for customers in order to capture value from customers in return. Moreover marketing is about obtaining customer loyalty, is about deploying long lasting vision into business. Reichheld and Schefter (2000) emphasize that: "To gain the loyalty of customers, you must first gain their trust".

For purpose of this paper we are going to segment the concept of Marketing into 4Ps and also analyze every P separately. It is necessary to be explained, because one of the main reasons of this research paper is to analyze the marketing mix of the Dea's Company. To do so, firstly is necessary to be shown the meaning of each one of the Marketing Mix elements. As described by McCarthy (1987) Marketing is established by the marketing mix that was called 4Ps representing:

- $\quad$ Product - is anything that can be offered to a market to satisfy a want or need, including physical goods, services, experiences, events, persons, places, properties, organizations, information, and ideas (Kotler \& Keller, 2012).

- $\quad$ Price - is the monetary value of a product or a service (Nykiel, 2003).

- $\quad$ Place - according to Blythe (2005), the product should be available from wherever the firm's target group of customers find it easiest to shop.

- Promotion - an intertwining of various activities by which the company communicates with individuals, groups or society in a form of personal or non - personal messages to harmonize its interests with their wishes (Keller \& Sudar, 1991). Communication is very important, because it makes costumers aware of the exitence of the product and also its value.

Four Ps have been useful only when applied to the product in context of marketing a physical goods, whereas for services, three more Ps were added to the model. In 1981 Booms and Bitner proposed a 7-P framework to include the following additional factors: people, processes, and physical evidences.

All this marketing mix strategy is compiled to fulfill target consumers' needs. Furthermore, to fulfill costumers' needs, it is necessary to apply market segmentation. According to McDonald and Dunbar (2004) market segmentation is the process of splitting customers, or potential customers, in a market into different groups, or segments. To execute the market segmentation, it is 
necessary to mention the different kinds of markets, which according to Kurtz (2008), are divided into two main groups:

1) Market of consumer products, which is characterized by customers who buy products for their personal use, such as cell phones, sports tickets, or fashion magazines; and

2) Market of business products, which is characterized by customers who buy goods and services for use either directly or indirectly in the production of other goods and services for resale.

To apply market segmentation in the market of consumer products, it is necessary to point the major segmentation variables, which according to Kotler and Keller (2012) are: geographic, demographic, psycographic and behavioral segmentation.

The geografic segmentation is defined as division of an overall market into a homogeneus groups based on their locations (Kurtz, 2008). According to Blythe (2005), this kind of variable is very commonly used in international marketing but is equally usefull within single nations. The demographic segmentation is concerned with the structure of the population in terms of ages, lifestyles, aconomic factors (Blythe, 2005). Acording to Kotler et al., (1999), the demographic segmentation consists on deviding the market into groups based on demographic variables such as age, sex, family size, family life cycle, income, occupation, education, religion, race and nationallity. The psycographic segmentation devides market into different groups based on social class, lifestyle and personality characteristics (Kotler \& Keller, 2012). The behavioral segmentation, accordind to Blythe (2005), examines the benefits, usage situation, the extent of use and loyalty.

When a firm implements the market segmentation, it is not necessary to apply all of those variables that are mentioned above. The firm can decide whether to use just one of them or combine some of them, depends on whatever is considered relevant for its success. When talking for bottled drinking water, one should have in mind that there are lots of consumers who cannot afford it. So looking at lowering cost of production might widen markets. Another segment that is worth looking into it is also the consumers who are concerned for the environment. Results of a research done by Pagiaslis and Krontalis (2014), show that concern for the environment has a positive and direct impact on environmental knowledge, beliefs, and behavioral intention.

The segmentation process is usually done to define the position of a firm in its markets. The market positioning represents the way the product is defined by customers on important attributes - the place the product occupies in consumers' minds relative to competing for products (Kotler, Amstrong, Saunders, \& Wong, 1999). As per Kotler and Keller (2012), the perceptual maps are usually used when we want a visual representation of customer perceptions and preferences: they provide quantitative portrayals of market situations and the way consumers view different products, services, and brands along various dimensions. According to Kotler et al. (1999), in their simplest form, perceptual maps use two dimensions: 1) value - price or money; and 2) quality, accessibility.

To evaluate a firm's success, it is necessary to draw a SWOT analysis. The WWOT analysis is also one of the main objectives of this paper. According to McDonald and Christopher (2003), the acronym SWOT derives from the initial letters of the words strengths, weaknesses, opportunities and threats. The strengths and weaknesses describe the state of the company. Whereas, the opportunities and threats describe the state of the market or markets in which the firm is actually operating.

We found the literature review helpful to define and implement the practical part of this research paper and to draw conclusions. 


\section{Research Methodology}

For our research purpose, we have used primary and secondary data. As secondary data, we have used the literature of certain authors to draw definitions and several publications from our institutions to reach information regarding to the bottled water industry in Kosovo, as well as we have used data from Dea's website to get some of the basic background information and the firm's products. In addition, we have investigated the use of social media (the company's official Facebook account) from the company as a promotion and communication tool with its customers.

As primary data, we have used the data we provided through qualitative methodology with indepth interviews with the company owner and the sales and marketing manager of the company. In addition, we have used the quantitative method of primary data collection through the questionnaire with around 200 respondents to have an overview of the positioning of this company in the market. The sample selected for this questionnaire was improbable and random, with respondents being residents of the Republic of Kosovo and consumers of bottled drinking water.

Scientific methods that have been used in this paper are historical, descriptive, analysis and generalization methods.

\section{Market and Competition Analysis}

\subsection{Summary of Water Sector Analysis in Kosovo}

It is estimated that Kosovo has only $1600 \mathrm{~m}^{3} /$ water/year per capita. Hydrographically, according to data from Kosovo Hydro meteorological Institute, Kosovo is divided into 4 river basins: Drini $\mathrm{i}$ Bardhë, Ibri, Morava e Binçes, and Lepeneci. Annually, the average humidity discharge from the territory of Kosovo is approximately $3.8 \times 10^{9} \mathrm{~m}^{3}$ water, respectively $121.2 \mathrm{~m}^{3} / \mathrm{sec}$. The main hydrological characteristic in Kosovo is the unequal and inadequate distribution of water resources compared to the needs. Hydro energy potential in Kosovo is very small and so far, its exploitation is rather modest. Groundwater reserves are limited and are mainly located in the western part of Kosovo, where surface water reserves are larger, compared to the eastern part with scarcer reserves and the south-eastern part where water needs are very large. Kosovo has a small number of natural lakes, whereas its artificial lakes are: Batllava, Gazivoda, Radoniqi, Perlepnica and Badovc, as well as a small number of irrigation lakes. Kosovo has important sources of thermal waters that are used for healing and recreation purposes. Protection, conservation and development of water resources is very important and one of the biggest environmental challenges in Kosovo.

Potable water in Kosovo is in line with International standards, and the overall quality of potable water in Kosovo that is offered to customers from the seven regional water companies and monitored by the NIPH Water Center, as part of its monitoring responsibilities, has achieved compliance of $96.3 \%$ with water microbiological quality standards and $97.3 \%$ compliance with chemical standards, resulting in a total compliance level of $97.0 \%$, a result after 43.000 tests made by six NIPH regional laboratories and NIPH Testing Laboratory Center in Prishtina during the 12 months of 2015. 
According to the data, about $69.6 \%$ of Kosovo's population is supplied with water through public systems which are managed by Regional Water Companies (RWCs), while about $29 \%$ are supplied with water from systems not managed by RWCs, or own systems, while about $0.7 \%$ of the population has no water supply service available. There are 7 regional potable water companies in Kosovo. In addition, there are many industrial water companies in Kosovo. 


\subsection{The Bottled Water Market}

Water as an important natural resource is irreplaceable. Therefore the maintenance, management and conservation of water resources as well as fresh water ecosystems are vital. Utilizing these water resources, in recent years in our country, the bottled water market has had a rapid development both in the global market and in the domestic market. This development is a result of private investment and donor support (MAFRD, 2019). Progress in this sector was achieved by expanding the range of products, which was made to meet the numerous demands and preferences of customers that were previously met by imported products. According to statistics from the Kosovo Agency of Statistics, in 2017, there are 25 large, small and mediumsized companies, registered in our country whose main activity is the production of bottled drinking water.

\subsection{Domestic Production}

Most of the production of bottled natural and mineral water comes from thermal water sources, from where the process of bottling begins in various quantities and is mainly sold as a wholesale contracted product in supermarkets, various institutions and hotels. Whereas another percentage of production is export-oriented which is increasing year by year. Thanks to professionalism and modern product line, some of the big companies are offering the required quality and quality in the international market. With numerous investments in factories, human resources and distribution network, in recent years there has been an expanded line of products, including glass and plastic bottled water in quantities of $0.25 \mathrm{I}, 0.75 \mathrm{I}, 1 \mathrm{I}, 1.5 \mathrm{I}, 2 \mathrm{I}$ and large plastic water of 5-10 and 19.5 I(MAFRD, 2019). Undoubtedly, the expansion of new product lines has made it possible for product excellence, rapid adaptation to customer needs, and successful expansion of companies. This is evidence that the private sector is progressing confidently towards economic prosperity, where, in addition to its positive and social effects, it is contributing inter alia to the creation of local brands of products currently being produced in Kosovo.

\subsection{Trade Development}

As domestic productivity is increasing as a result of capacity expansion and application of modern technology, quantity and quality have increased significantly in recent years. To meet the population's demand for bottled drinking water, in addition to domestic production a significant amount of this product is imported, including varieties from many countries around the world. Imports of this product in 2010-2016 averaged 104,165 tons per year, increasing depending on market demand (MAFRD, 2019). According to statistics from the Kosovo Agency of Statistics, the largest amount of imports was in 2015 with 119,837 tons, while in 2017 this amount was 112,988 tons. After researching foreign market requirements and the ability of some companies to penetrate markets abroad, part of the production is being exported to both countries in the region, the EU, and many distant countries in the world market such as: Arab countries, Africa and Australia (MAFRD, 2019). In terms of export, the average exported water for the period 20102016 was 12,700 tones / year, while in 2017, this amount reached 24,682 tones, which is an increase of $94.3 \%$, compared to the average of $2010-2016$ (MAFRD, 2019). Regarding the amount of exported water, the most successful year so far was 2017 . If we analyze the export 
value by months in 2017 , it turns out that July was characterized by a higher export value, which was 1.3 mil. $€$, followed by August 1.2 mil. $€$ and May 1.1 mil. $€$. Whereas, January was the month with the lowest value or 255 thousand $€$ (MAFRD, 2019). The other months were worth more than January or less than July.

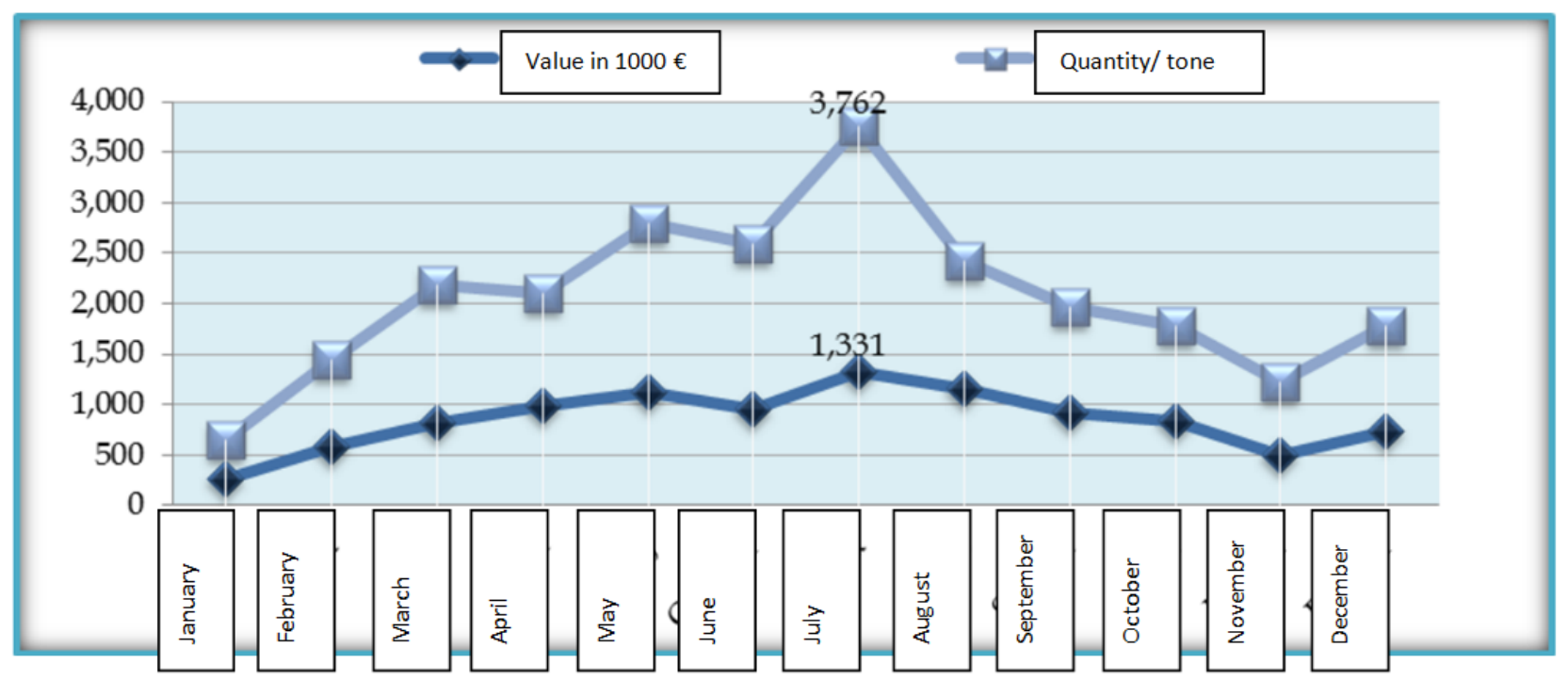

Figure 1. Value and quantity of export of bottled water by months, in 2017 Source: ASK, processed by DAESB - MAFRD

In terms of imports the largest amount of water was imported during July with 3,762 tons, followed by May 2,762, June with a quantity of 2,587 tons, as well as in August with 2,428 tons. The smallest amount of water has been imported in January 2017, where they were imported only 645 tons (MAFRD, 2019).

\subsection{The import of bottled water}

The amount of imported water has been decreasing and increasing year by year, depending on the availability of domestic production and market demand. According to statistics from the Kosovo Agency of Statistics, the years 2011 and 2012 are presented as the years with the smallest amount of imported (996 thousand tons), while the largest amount was in 2015 in the amount of 119,837 tons. Referring to the figure below, if we compare the amount of imports in 2017 (112,988 tons) with the highest amount of imports for these years that was in 2015, it follows that in the last year there is a decrease in the amount of imported water by $5.7 \%$. 


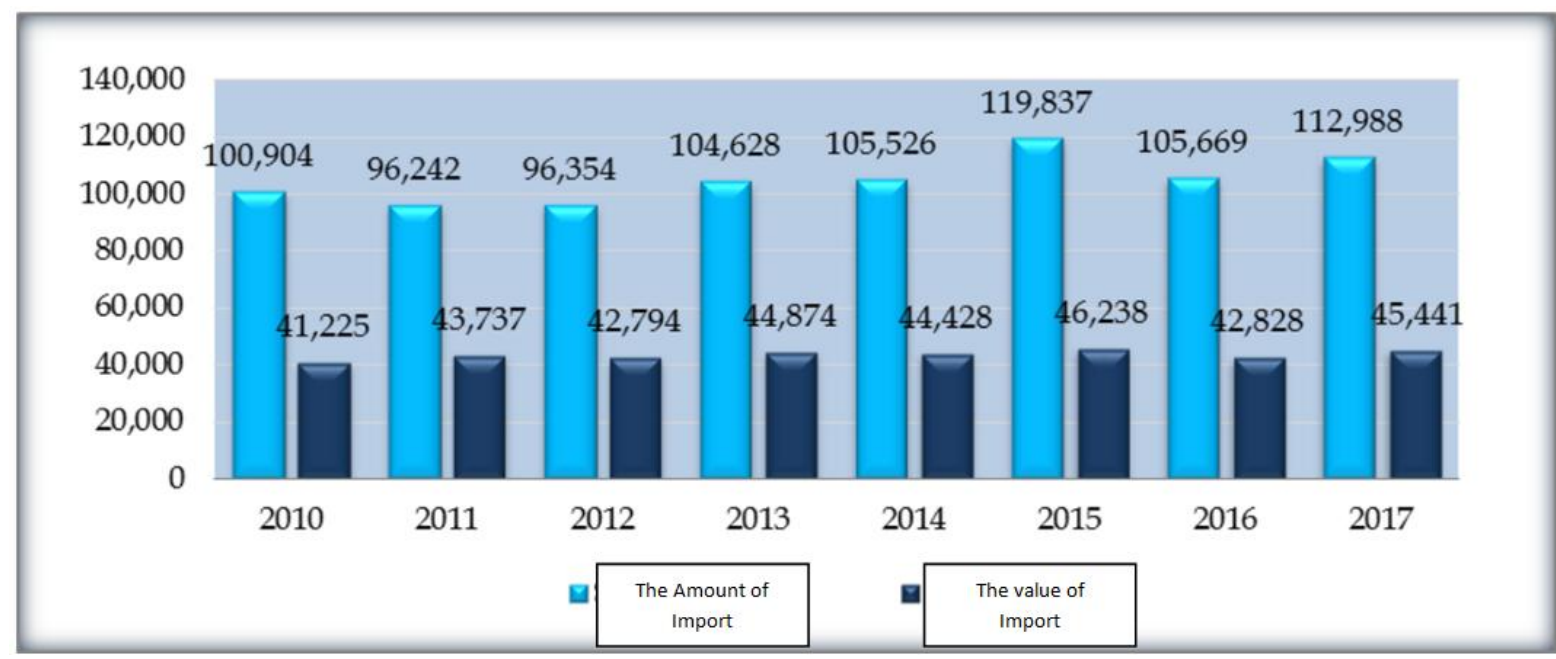

Figure 2. Import of bottled water for the years 2010-2017, value (in $1000 €$ ), amount (in tons). Source: KAS, processed by DAESB - MAFRD

The above figure shows that the average value of imports for the period 2010-2016 was 43.7 mil. $€$. This value is approximate to the value of import in 2017 , which was 45.4 mil. $€$ which unlike the average of $2010-2016$, is up by $3.9 \%$. The highest value of imported drinking water in the period 2010-2017 was in 2015, which was worth $€ 46.2$ million.

Figure 3 shows the countries from which water was imported in 2017. It is mostly imported from Serbia with a share of $75 \%$ of imports, followed by Albania $11 \%$, Turkey $4 \%$, Croatia $2 \%$ and Slovenia $1 \%$. These countries account for $93 \%$ of imports, while countries grouped with others account for only $7 \%$.

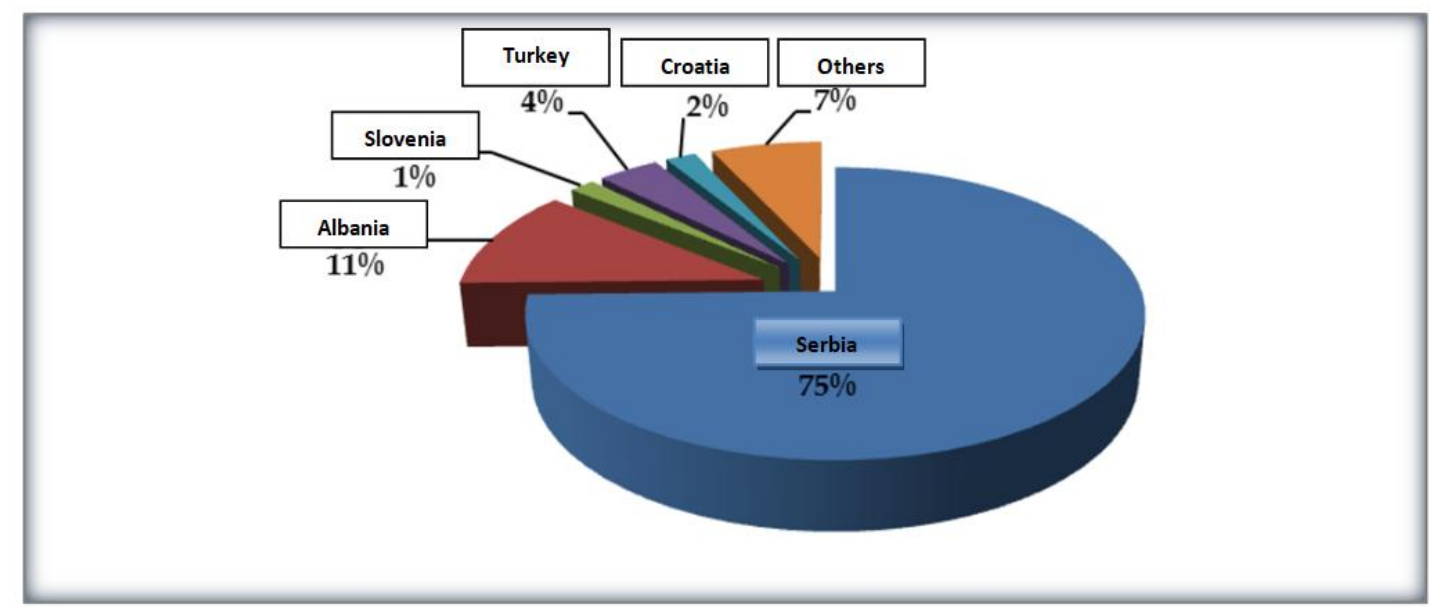

Figure 3. The amount of imported bottled water by country in 2017 (\%)

Source: KAS, processed by DAESB - MAFRD 


\subsection{The Export of bottled water}

According to data from the Kosovo Agency of Statistics, the highest value of fresh water export was achieved in 2017, at a value of 10.1 mil. $€$. On the other hand the lowest value was in 2010 , with only 2.3 mil. $€$. The value of water export in 2017 , compared to 2016 , increased by $83.9 \%$.

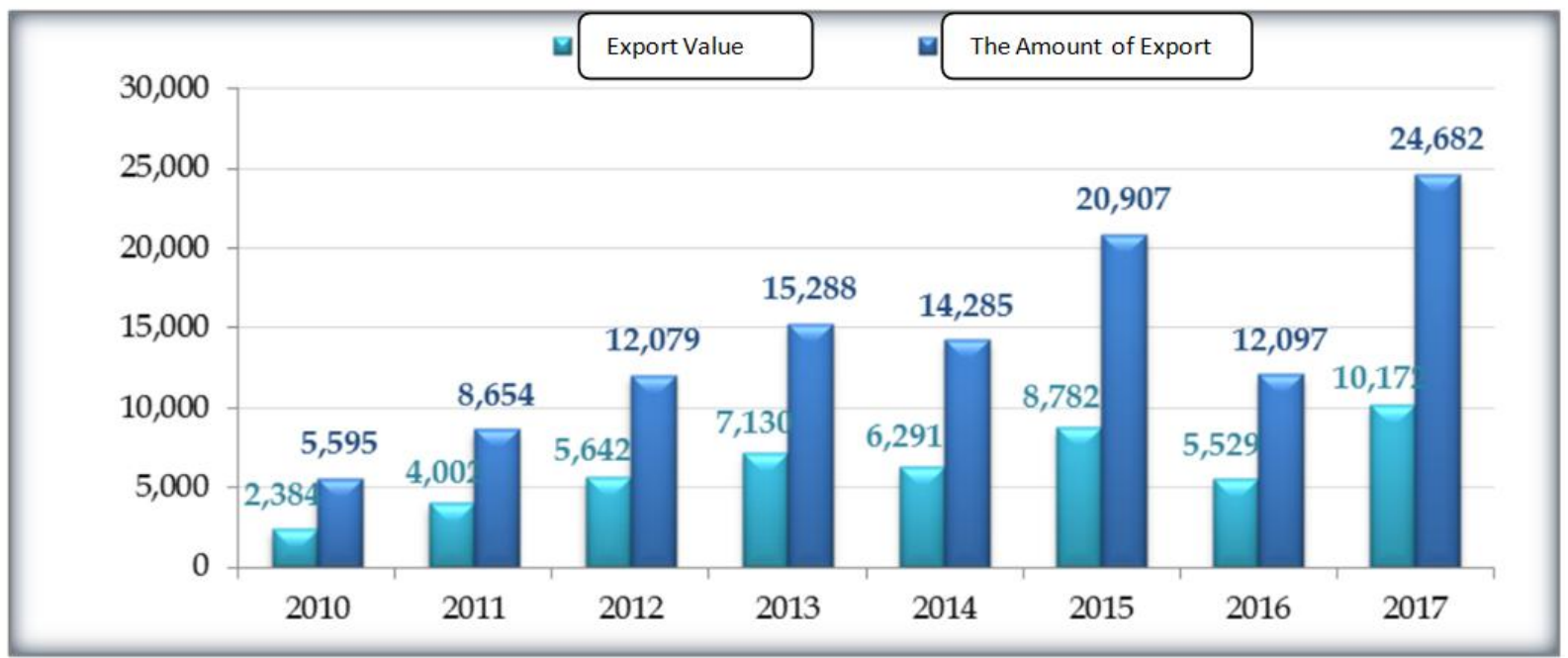

Figure 4. Export of bottled drinking water 2010-2017, value in $1000 €$, quantity in tons.

Source: KAS, processed by DAESB - MAFRD

In terms of export by country, the highest percentage of water was exported to Macedonia $31 \%$, followed by Albania 17\%, Bulgaria 10\%, Romania 7\%, Montenegro 6\%, Switzerland 4\%, followed by Serbia and Italy with $2 \%$, and in countries grouped as "Other" 21\% (MAFRD, 2019).

\subsection{The size of the market}

According to the statistics of the Kosovo Agency of Statistics, it is estimated that the total water market in Kosovo in 2017 is estimated to be around 64.6 million $€$. This includes the value of all domestic production ( $€ 19.2$ million) as well as imports ( $€ 45.4$ million). The value of domestic production of bottled water in 2017 has a share of $29.8 \%$ in the market of this industry, while the value of imported water accounts for $70.2 \%$.

\subsection{Promotion and challenges}

For years in Kosovo, the Agency for Investment and Enterprise Support KIESA at the Ministry of Trade and Industry, organizes fairs to promote different businesses, in this case also businesses that produce bottled water are very present with the variety of their products. These fairs, which are now national and regional in character, are influencing public opinion on local drinking water production and the type of products offered by local companies and promoting the consumption of local products. It should be noted that, at the events organized by the World Drinking Water Association, three major Kosovar companies were awarded for water quality and adequate packaging ${ }^{1}$ : in the "International Quality Award ${ }^{1}$ ", in "World of Premium Waters ${ }^{2 ",}$ "Business

\footnotetext{
${ }^{1}$ http://www.finewaters.com/bottled-waters-ofthe-world/kosovo
} 
Initiative" Directions "with the ERA Platinum Award in the category" International Quality Awards ". The high quality has enabled the two companies' water to be sold in Switzerland in 500 Coop food chain stores, which have enriched their shelves with Kosovar products. One of these companies also supplies water to the US military base in Kosovo, Bulgaria, Romania, Germany, Hungary, Croatia, Slovenia, foreign embassies as well as many foreign and domestic institutions. The water produced in our country has found its way into some supermarkets in other European countries, generally where our compatriots live.

The main barriers of doing business in this sector include: lack and high cost of electricity, high tax rates, access to credit, corruption, lack of purchasing power in local markets, lack of workers. lack of specialized graduates, difficulties in marketing products abroad especially in countries that have not recognized Kosovo, high costs of skilled workers and some other difficulties.

\subsection{The Profile of DEA Company ${ }^{3}$}

The inception of Adea Group is closely linked with the overall drive of Kosovo society to strengthen and develop the private economy. Adea Group was founded in 1990 by brothers Shala. Furthermore, since than Adea Group became one of the key bearers of the economic development in Gjilan region and beyond. Adea Group is proud to state that has been in business more than 19 years and has established a proven quality history that is considered to be excellent. Adea Group is committed to continually upgrade and expand the production program and services comprised of a diversified range of activities while maintaining a strong capital position.

DEA as one of the branches of the Adea Group started production in 2004. In the first two years, the company has successful penetration in the market and a rapid growth of market shares. This was due to the good quality of its products as well as properly targeted promotion. During this period, they expanded the product lines and keen on continuing the expansion, based on customer requirements. Regarding the standards for bottled water, DEA meets all global standards for bottled water, and in 2006 DEA was certified with ISO 22000 and HACCP, which certifies production safety and continuous quality improvement. The quality of Natural Mineral Water DEA has been confirmed by KFOR, where DEA is the main supplier for KFOR, NATO base, International Embassies, as well as many foreign and local institutions. The products of the "DEA" company are: natural water DEA; mineral water DEA and natural mineral water for babies.

\subsection{Market Segmentation}

Dea Company managed to be present throughout Kosovo territory with its products. Since DEA produces products with a different access to the market and various product demand with natural water there is a non-elastic demand whereas with the other two types of its products there is an

\footnotetext{
${ }^{1}$ http://www.wqa.org/awards

${ }^{2}$ http://premiumwaters.co.ke/index.php/lightingdesign

${ }^{3}$ http://ujidea.com/sq/company.html
} 
elastic demand. Thus, market segmentation for these types of products is done in different ways and taking into account various variables for market determination.

In the production of natural water DEA, according to data provided by the sales sector of the company, market segmentation is based on the geographic/territorial variable where its customers are assessed for entry in the market segment, broken down by certain regions where customers have a higher appreciation for the quality than the price (Prizren, Mitrovica and Peja regions) and the region where they prefer lower price rather than the quality (Kaçanik, Vitia, Vushtrria, Gjakova, Rahoveci, Malisheva, Podujeva). ${ }^{1}$

In the production of mineral water "DEA" and natural mineral water for babies, the market segmentation is also based on the geographic/territorial variables, but also on other variables such as: demographics/age of consumer, where the water for babies is intended for infants from 0-3 years of age, a market that is more targeted by the company because children are the main consumers of water for babies, while natural mineral water consumers come mainly from adults aged 20 and over; behavioral variables/consumption rate of DEA products compared to the same or similar competition products.

Based on the above, consumers of DEA products may be divided into three groups:

- Households - consuming bottled water.

- "Casual" Customers - Adults in Special Occasions (water consumption during travel, picnics, working hours, etc.).

- Children aged 0 to 3 years - water for babies.

In addition, DEA managed to be the supplier of many natural and mineral water institutions, such as: Parliament of Kosovo, most of embassies in Kosovo and other institutions. In addition, natural mineral water DEA is exporting to countries such as Albania, Macedonia, Switzerland and Germany.

After its success in the European market, company also targeted Turkey. According to the owner of the company they are the largest producers in Kosovo, with the largest capacities and highquality water, valued by the German, Swiss, French and American institutes. He stated that the technology is of European standards and that the production is in line with ISO standards (high standard) monitored by the Swiss Institute, which preconditions led to the company's significant success.

\subsection{SWOT Analysis}

SWOT analysis (or SWOT matrix) is a strategic planning technique used widely to help an organization identify its strengths, weaknesses, opportunities, and threats related to business.

\begin{tabular}{|l|l|l|l|}
\hline Strengths: & Weaknesses: & Opportunities: & Threats: \\
\hline $\begin{array}{l}\text { - experience in water } \\
\text { production; }\end{array}$ & $\begin{array}{l}\text { - lack of promotion; } \\
-\end{array}$ & $\begin{array}{l}\text { - limited marketing to attract new } \\
\text { markets; }\end{array}$ & $\begin{array}{l}\text { Strong } \\
\text { international and }\end{array}$ \\
\hline
\end{tabular}

\footnotetext{
${ }^{1}$ Interview with sales manager at DEA
} 


\begin{tabular}{|c|c|c|c|}
\hline $\begin{array}{l}\text { - modern technology } \\
\text { for the production of } \\
\text { natural water and } \\
\text { mineral water; } \\
\text { - first in the market to } \\
\text { produce special water } \\
\text { for babies } \\
\text { - capacities for mass } \\
\text { production consumer } \\
\text { - } \\
\text { confidence in } \\
\text { company's product; } \\
\text { - flexible and } \\
\text { experienced in price } \\
\text { adjustment; } \\
\text { - a good distribution } \\
\text { channels; }\end{array}$ & $\begin{array}{l}\text { budget for new } \\
\text { products; }\end{array}$ & $\begin{array}{l}\text { - expansion of } \\
\text { production assortment } \\
\text { with other products } \\
\text { such as: water with } \\
\text { natural flavors and } \\
\text { essences; } \\
\text { - possibility to reduce } \\
\text { fixed costs as a result } \\
\text { of increased sales } \\
\text { volumes; }\end{array}$ & $\begin{array}{l}\text { national competition; } \\
\text { risk of new entrants in } \\
\text { the market } \\
\text { eventual unforeseen } \\
\text { government change } \\
\text { of policies for the } \\
\text { sector; }\end{array}$ \\
\hline
\end{tabular}

Table 1. SWOT Analysis for Dea Company

\subsection{Competition Analysis}

Competitive analysis is a field of strategic research that focuses in the collection and review of information about rival firms. It's an essential tactic for finding out what competitors are doing and what kind of threat they present to financial well-being of a firm.

Competition analysis for DEA products has been done separately for three types of products, natural water, mineral water and water for babies.

- Competition for natural and mineral water

Although there is enough competition in the market for different types of water products, DEA is recognized in the market as a powerful natural water production company. The reason why it is a powerful competitor is the quality of source water which is extracted and processed by DEA. The company's competitors are divided in two groups:

Local producers: the main ones include: Rugove Company (for natural water), Miros Company, Uji i Alpeve, and Spirit of Drini.

Foreign producers: the main ones are: Spring water, Rosa water, San Pellegrino water, Tepelene water, etc.

- Competition for water for babies:

The local competition for this category of water in Kosovo is insignificant. DEA Company was the first one to succeed in creating such a product, followed by the RUGOVE Company which created "Water" for Children this year, but there is no water specifically dedicated to babies aged 0 to 3 . 
As for the competition of products coming from foreign countries, the main competitor is the HIPP Company, which is known as the leading provider of baby products. However, this competitor offers water quality at a higher price than DEA. Whereas, DEA offers the similar quality product but also at a reasonable and affordable price for our population.

\subsection{Market Positioning}

We will present the market product positioning for three types of products separately, taking into account two variables: quality and price, and comparing them with competing products.

\section{The position of natural and mineral water DEA in relation to some of the local and foreign competitors:}

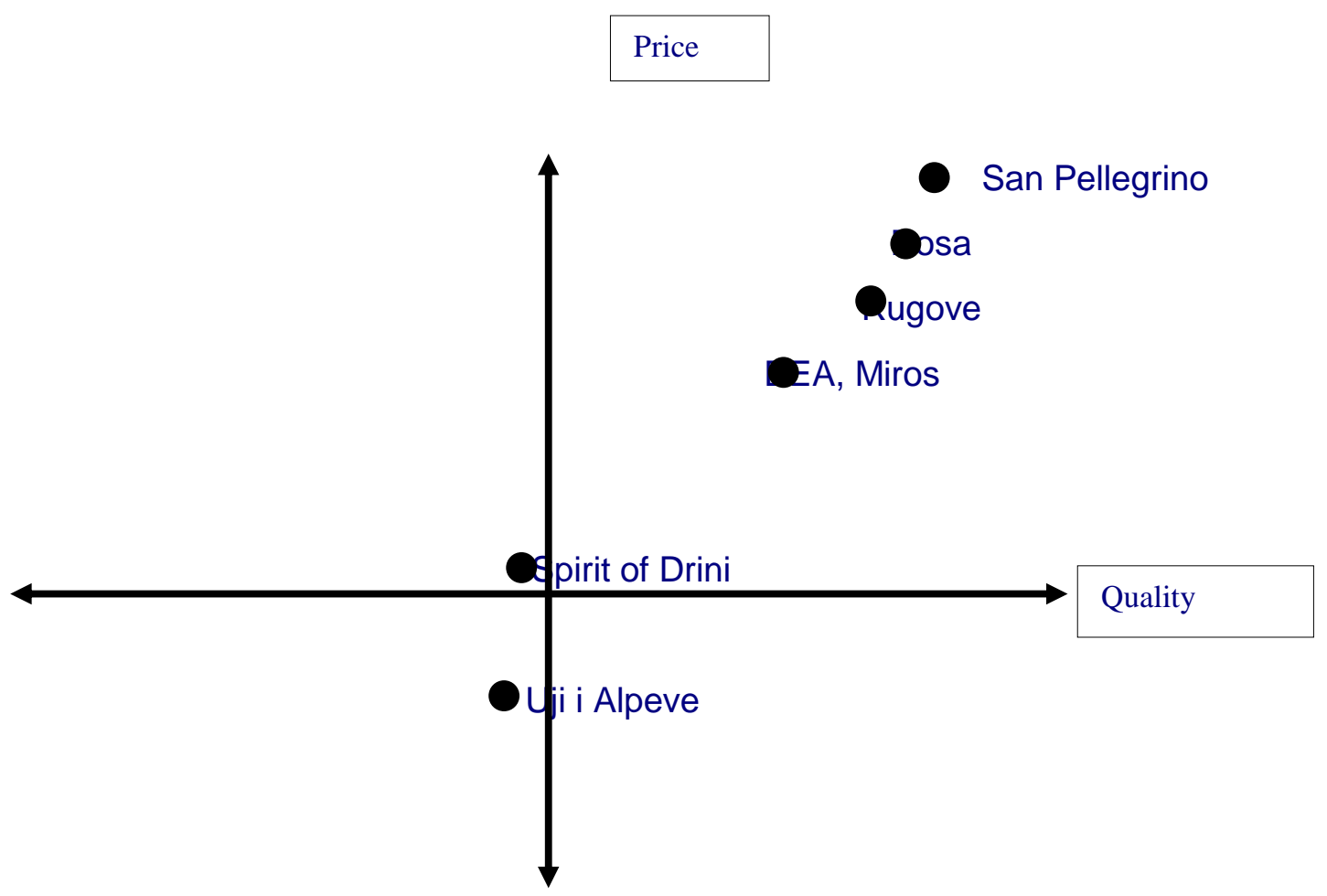

Figure 1. The positioning of Natural and Mineral Water Dea

From this diagram we can see that DEA water, both in price and quality stands higher than its two competitors, namely the Spirit of Drini and the Uji i Alpeve. As for Miros water, as shown in the graph they are equal competitors in terms of price and quality. From local producers, only Rugove water is positioned higher for both quality and price. Also, two foreign competitors, San Pellegrino and Rosa, are positioned higher in the minds of consumers in Kosovo compared to the water DEA. As noted, company DEA and the other domestic water company, Rugove, mainly target quality-based customers, while other local competitors target customers who are after lower prices. 


\section{Firm positioning with for water for babies product:}

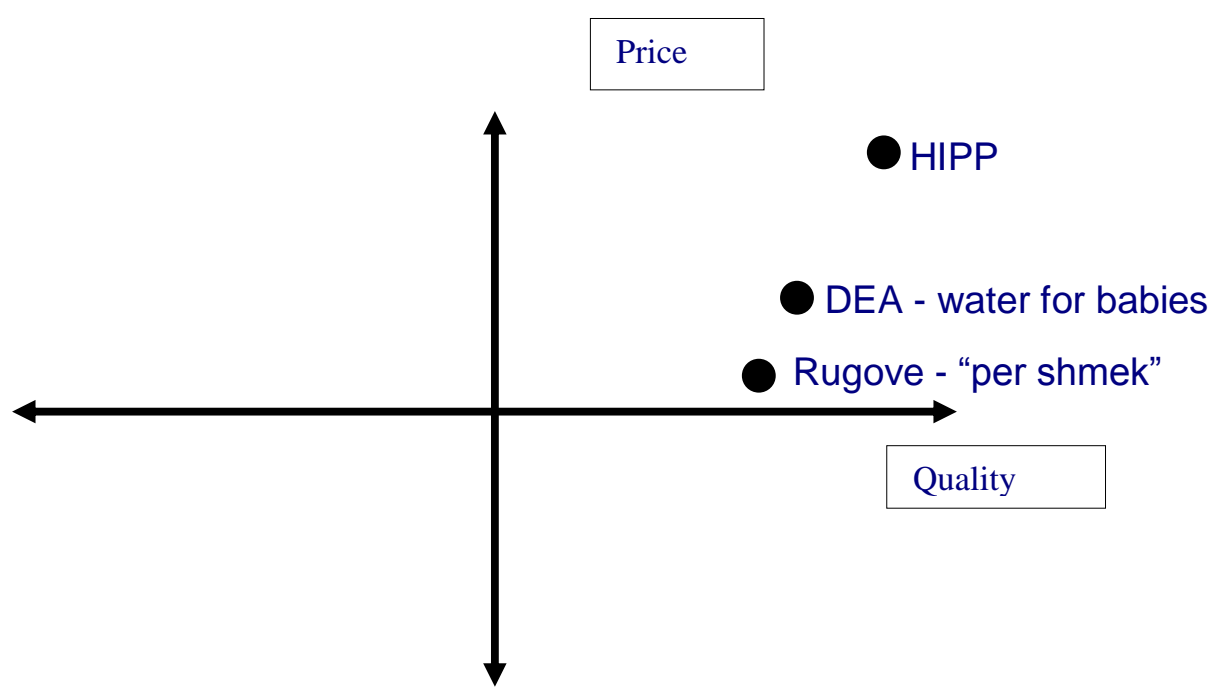

Figure 2. Firm positioning with Water for Babies product

From what is seen in the diagram, we can notice that the DEA water product "water for babies", both in terms of quality and price, is higher than the Rugova competitor's product "per shmek" . Whereas, compared to the children's food and water giant, HIPP, the latter is positioned far above, both for quality and price. However, given the circumstances of doing business in Kosovo, and given the fact that we are still a newly established state, this company managed to succeed in creating such a position in our market.

\section{$4 \quad$ Marketing Strategy - Marketing Mix}

\subsection{Product Policy}

As noted above, DEA produces three types of water: natural water, mineral water and water for babies. Below are the detailed attributes of these products:

Natural water DEA; Natural Mineral Water DEA extracted from the depths of underground of Zhegoc Mountains, is one of the lightest oligo mineral waters and possesses a sufficient amount of minerals that are necessary for the functioning of the body and its stabilization. Water DEA is rich in bicarbonate, sulfate, calcium, magnesium, which makes DEA water suitable for those who need to escape from carbonated drinks, those suffering from gastritis and those in need to drink large quantities of water.

1 liter of water contains the following in $\mathrm{mg} / \mathrm{dm}$ :

- Cations: Calcium 28.00, Magnesium 5.48, Sodium 86.00, Potassium 4.27

\footnotetext{
${ }^{1}$ https://rugove.eu/en/products/water-rugove/
} 
- Anions: Bicarbonate 332.00, Sulfate 22.00, Chloruretics 9.80, Nitrate 0.70

This type of water is offered in different sizes and in different packages:

- 0.25 liters of glass packaging

- 0.5 liters of plastic packaging

- 0.75 liters of glass packaging

- 1.5 liters of plastic packaging

- 2 liters of plastic packaging

- 6 liters of plastic packaging

- 8 liters of plastic packaging

- 19.5 liters of plastic packaging

Mineral water DEA; Natural Mineral Water DEA extracted from the depths of the underground is rich in minerals such as bicarbonates, sulphates, calcium and magnesium, and has a very good effect on the physiological functioning of the human body. Mineral Water DEA in the source always stems at a constant temperature, indicating the stability of the soil layers. It can be used during the treatment of the following diseases: Chronic gastric disease, removing sand in urinal tract, treatment of chronic bladder diseases.

One liter of water contains the following in $\mathrm{mg} / \mathrm{dm}$ :

- Cations: Kalcium147.49, Magnesium 41.83, Sodium 210.00, Potassium 37.50.

- Anions: Bicarbonate 1232.00, Sulfate 22.00, Chlorine 9.80, Nitrate 0.70.

This type of water is offered in different sizes and in different packages:

- 0.25 liters of glass packaging

- 0.5 liters of plastic packaging

- 0.75 liters of glass packaging

- 1.5 liters of plastic packaging

- 2 liters of plastic packaging.

Products in glass packaging and large containers are intended for business consumers, i.e. for restaurants, cafes, institutions, etc., while plastic packaging products from 0.5 liters to 2 liters are mainly intended for consumers of broad consumption.

DEA water for babies: DEA is very crystal clean water, and thus is dedicated to babies and children. There is a sufficient amount of calcium and magnesium that is essential for the normal development of babies. Baby Water DEA is very pure crystal water, dedicated to infants and children. It can also be used to prepare baby food. There is a sufficient amount of calcium and magnesium that is essential for the normal development of babies. This type of water is offered in plastic packaging and in 1 -liter bottles. 


\subsection{Pricing Policy}

According to Kotler and Amstrong (2012), the price represents the amount of money required for a product or service, or the amount of values that customers exchange with the benefit of owning or using a product or service. Considering the marketing mix, none of the one 4Ps or 7Ps should be decided in isolation. Charging the right price to the target consumers is one of the key elements to business's success. Hence choosing the right pricing strategy it seems challenging to every company. One should charge the price that correspond to the positions of the products in the mind of costumers, moreover price should be in line with all other elements of marketing mix. If the company fails in setting the right, it will fail. Failures can be of two types: if the product price is lower than the costs of production for the product, the company will fail and go bankrupt as there will be no financial capacity to cover the costs; also, if the price is appropriate for the company and according to internal analysis such price can cover the costs, but the product at that price is not accepted by the consumers as they consider it high for the perceived value of the product, it will also lead to failure.

For this reason, DEA Company, from what we learned in the interview with the owner and the marketing and sales manager, paid attention to pricing policies for its products.

There are various price definition policies, and authors Pride and Ferrell (2003) note three main methods for this exercise:

- $\quad$ Cost based pricing where a certain amount or predefined percentage of money is added to the total cost of the product as a profit rate.

- Customer demand-based pricing - a method in which prices are defined based on the demand for the product.

- Competition based pricing - a method whereby the company defines prices for its products based on how the competition acts.

According to the data provided by the interview with the DEA Marketing and Sales Manager, it has been proved that this company, both domestically and abroad, uses the combination of the above two methods to determine the prices of its own products, respectively, uses the pricebased method of cost-based and competitive-based approach. According to them, it is necessary to set a price that ensures a return, and a price which is not higher than that of the foreign competitors and not higher than the main competitor Rugove water.

Current prices of Dea Natural water are shown below:

0.25 liters of glass packaging - 0.30 Euro

0.5 liters of plastic packaging - 0.20 Euro

0.75 liters of glass packaging - 0.65 Euro

1.5 liters of plastic packaging - 0.60 Euro

2 liters of plastic packaging -0.75 Euro

6 liters of plastic packaging - 1.5 Euro

8 liters of plastic packaging -2.5 Euro 
19.5 liters of plastic packaging - 5.00 Euro.

Princes of Dea Mineral water are shown below:

0.25 liters of glass packaging - 0.40 Euro

0.5 liters of plastic packaging - 0.29 Euro

0.75 liters of glass packaging - 0.75 Euro

1.5 liters of plastic packaging - 0.80 Euro

2 liters of plastic packaging - 0.95 Euro

Whereas baby water in a 1 -liter package, costs about 0.90 Euros.

\subsection{Distribution}

Regarding the forms of distribution, for final consumers in the territory of Kosovo, DEA company uses the level 1 of the distribution, i.e. It uses only one type of intermediaries, namely only retailers, as the company makes the transport to them itself, with its own means of transport. Regarding the distribution of products in the region and beyond, it utilizes level 2 distribution channels, namely granting exclusive distribution rights to one retail reseller per country, which, in turn, sell its products to end-customers.

Dea Company, in addition to final consumers, sells its products to business customers, such as various restaurants, cafes, etc., as well as Kosovo's institutions. To sell products to these categories it does not use dealers, but rather it uses its agents.

\subsection{Promotion and Advertising Policy}

The promotion represents all the tools the company uses to communicate with customers. If the company produces the right product, has the right price, makes the right distribution but fails to apply the right promotion form, then no one will be informed of the company and the products in question, and ultimately no one will buy its products.

Thus, knowing and acknowledging the importance of promotion, DEA has also paid attention to this part. According to data from the interview with the sales and marketing manager, the company uses mostly advertising as a form of promotion for all types of its products. This is because most of the products of the company are dedicated to a broad range of customers. While communicating with business customers, they mostly use personal sales coupled with sales incentives to lure them to get their products as much as possible.

As far as advertising is concerned, they are mainly applied in the classical media, such as national television, local and national radio, and in the daily "Epoka e Re", and twice a month in the daily "Koha Ditore". Modern media used by the company to communicate with its current and potential customers are its web site: http://ujidea.com/; there is also the official Facebook account, even though the page is not regularly updated and does not ensure decent communication with customers, hence they are not fully active.

It also started to use online portals, namely e-newspapers to advertise its products, such as telegrafi.com and expressonline.com. 
The company does not significantly use, if any, the promotion of sales to large customers, as it is used for example by its competitor Rugove. Also, the company does not use billboards or leaflets as advertising tools. Dea is not envolved in any helath campagne, which would help it to promote its products.

\subsection{Current Domestic Markets}

The table below presents current domestic markets of DEA Company and its market share in total sector sales. Data from the last census in Kosovo show that its population is around 1.7 million inhabitants. If bottled water production company DEA covers around $5 \%$ of the Kosovo market, the distribution of DEA products in the main Kosovo regions is presented in the table below:

Table 1. Current Markets of Dea Company

\begin{tabular}{|c|c|c|}
\hline Market & Total sales in 2017 / units & $\begin{array}{l}\text { Percentage of } \\
\text { total sales }\end{array}$ \\
\hline Prishtina & $9,307,500.00$ & $30 \%$ \\
\hline Gjilan & $12,410,000.00$ & $40 \%$ \\
\hline Ferizaj & $3,257,625.00$ & $10.5 \%$ \\
\hline Mitrovica & $1,396,125.00$ & $4.5 \%$ \\
\hline Pejë & $1,085,875.00$ & $3.5 \%$ \\
\hline Prizren & $2,171,750.00$ & $7 \%$ \\
\hline Gjakovë & $1,396,125.00$ & $4.5 \%$ \\
\hline Total sales & $31,025,000.00$ & $100 \%$ \\
\hline
\end{tabular}

As presented in the table above, the Kosovo region that is mostly covered by the company's products is Gjilan region, since the company's headquarters are located in this region.

\subsection{Current Foreign Markets}

Table 2. The sales data of Dea Company for 2017

\begin{tabular}{|c|c|c|}
\hline Market & Total sales in 2017 / units & $\begin{array}{l}\text { Percentage of } \\
\text { total sales }\end{array}$ \\
\hline Albania & 600,000 & $40 \%$ \\
\hline Macedonia & 400,000 & $30 \%$ \\
\hline Switzerland & 250,000 & $21 \%$ \\
\hline Germany & 150,000 & $9 \%$ \\
\hline Total sales & $1,400,000$ & $100 \%$ \\
\hline
\end{tabular}


The sales data provided herein is approximate and provided for illustration purposes only, to delineate the extent and magnitude of the market.

\subsection{Target Markets}

In the table below are presented the new markets of Dea Company as the company tends to penetrate the new markets abroad.

Table 3. Target markets of Dea Company

\begin{tabular}{ll}
\hline Market & Total envisaged sales \\
\hline Montenegro & 100,000 \\
Austria & 200,000 \\
Belgium & 200,000 \\
Scandinavian countries & 300,000 \\
$\quad$ Total sales & 800,000 \\
\hline
\end{tabular}

According to data obtained from the interview with the company's sales and marketing manager, the first country targeted for expansion is Montenegro, due to its geographical proximity and ease of market penetration. In addition, the standard of living in this country is similar to that in Kosovo, providing for easier product acceptance by the market. Penetration in other markets and countries is expected in early coming years.

\section{Conclusions and Recommendations}

According to the finding derived from this research paper, we could conclude that the bottled water production in Kosovo has been increased year by year. In addition the imports are being reduced compared but in the other hand, the value of exports of the bottled water is increasing. Also, the share of market is gradually being dominated by domestic producers. Even though there are a lot of challenges companies of this sector need to manage if they want to have success in this sector in Kosovo and abroad.

The elaborations in this paper lead to the conclusion that Bottled Water Production Company DEA is a stable company with considerable profits since from the beginning of its operation. The firm is dedicated to expanding the spectrum of its products with new water types and bottling sizes that defy the standard water bottling practices, and which has introduced a new product for the domestic market - DEA baby water.

Product differentiation should be granted special attention, because of the product specificities. At this stage, we suggest that the company should focus on timely product distribution and delivery to maintain its position on the market. Sales representatives should act with caution and leave a good impression with customers since only highly "customer oriented" staff can win customers from competitors and then keep these customers and grow them by delivering greater value (Kotler \& Amstrong, 2012). In addition, they should be attentive to customer needs and demands 
and get instant customer remarks, concerns and advice as precious feedback in the companycustomer communication.

Additionally, to achieve greater growth in the existing or new markets, and increase its sales, the company should utilize better and more efficiently modern media and new means of promotion. The study above shows the tendency of this company is to utilize mostly advertising as means of promotion (for general market consumption), alongside personal sales (for commercial customers). It uses sales enticement very seldom and that only for accompanying personal sales to commercial customers. Public Relations are not properly managed in either quantity or quality, resulting in the failure to create positive publicity for the company (Fejza \& Ukaj, 2014), DEA should utilize identical or similar means if it wishes to maintain or grow its market share or expand to new markets. Company should start involving in heath campaigns and sponsorship of different activities, more over social responsibility is one of the areas that company should shift in.

We strongly believe DEA will manage to keep all the pieces of production chain highly functional; otherwise, the 'weakest link' of the chain will damage the whole system.

At the end another segment that company should focus is consumers that care for environment, as their number is growing every day. Applying green marketing and friendly environment material might help the company to keep up with good image and grow for better.

\section{$6 \quad$ Literature}

Blythe, J. (2005). Essentials of Marketing. Third Edition. Harlow, England: Pearson Education Limited.

Booms, B., \& Bitner, M. (1981). Marketing strategies and organization structures for service firms, in Marketing of Services. Chicago : American Marketing Association.

Keller, K. L., \& Sudar, J. (1991). Promocija. Zagreb.

Kotler, P., \& Armstrong, G. (2016). Principles of Marketing. 16th Edition. Pearson Education Limited Edinburgh Gate, Harlow, Essex CM20 2JE, England.

Kotler, P., \& Amstrong, G. (2012). Parimet e MArketingut [Principles of Marketing]. 13th Edition. Tirana: UET Press.

Kotler, P., \& Keller, K. L. (2012). Marketing Management. 14th Edition. New Jersey: Pearson Education, Inc., publishing as Prentice Hall.

Kotler, P., Amstrong, G., Saunders, J., \& Wong, V. (1999). Principles of Marketing. Second European Edition. New Jersey: Prentice Hall Inc.

Kurtz, D. L. (2008). Contemporary Marketing. 13th Edition. Mason: South Western.

McCarthy, E. J. (1987). Basic Marketing: A Managerial Approach, 9th edition. Irwin: Homewood, IL.

McDonald, M., \& Chirtopher, M. (2003). Marketing. A Complete Guide. New York: Palgrave Macmillan. https://doi.org/10.1007/978-1-4039-3741-4

McDonald, M., \& Dunbar, I. (2004). Market Segmentation. How to do it? How to profit from it? Oxford: Elsevier Butterworth-Heinemann. 
Nykiel, R. A. (2003). MArketing Your Business. A guide to developing a strategic marketing plan. New York: The Haworth Press, Inc.

Pride, W., \& Ferrell, O. C. (2003). Marketing Concepts and Strategies. 12th Edition. Boston: Houghton Mifflin Company.

Pagiaslis, A., Krontalis, A. K. (2014) "Green consumption behavior antecedents: Environmental concern, knowledge, and beliefs", Psychology \& Marketing, Volume 3. https://doi.org/10.1002/mar.20698

Reichheld, F.F. Schefter, P. (2000). E-loyalty your secret weapon on the Web. Harvard Business Review, 78 (4).

Data obtained in an interview with owner of DEA Company, and its sales and marketing manager

Sources from internet:

http://ujidea.com/sq/company.html

http://rajonipress.com/shfleto-artikuit.php?id=13780

https://rugove.eu/en/products/water-rugove/ 